\title{
A Review and Classification of Integrated Project Delivery Implementation Enablers
}

\author{
Zahra Kahvandi', "Ehsan Saghatforoush², Ahad ZareRavasan³ \\ and Marina Lapa Viana ${ }^{4}$
}

First submission: 30 November 2019; Accepted: 30 May 2020; Published: 15 December 2020

To cite this article: Zahra Kahvandi, Ehsan Saghatforoush, Ahad ZareRavasan and Marina Lapa Viana (2020). A review and classification of integrated project delivery implementation enablers. Journal of Construction in Developing Countries, 25(2): 219-236. https://doi.org/10.21315/jcdc2020.25.2.9.

To link to this article: https://doi.org/10.21315/jcdc2020.25.2.9

\begin{abstract}
In the current competitive and complex business environment, innovation in the construction industry is vital. In this sense, integrated project delivery is an emerging delivery system for construction projects; however, implementing this system requires some enablers to enhance its implementation. Until now, no study has been conducted to identify what enablers can lead to proper integrated project delivery implementation. Therefore, this study aims to identify and to classify integrated project delivery implementation enablers. In this study, a comprehensive list of integrated project delivery implementation enablers has been developed using an in-depth literature review. Besides, integrated project delivery project managers, employers, consultants, contractors and engineers participated in a survey. The obtained results were analysed using exploratory factor analysis method. Thus, the study findings illustrated that organisational enablers are considered essential enablers, followed by environmental, contractual and technical enablers. The significance of this research is the identification and classification of integrated project delivery implementation enablers, which will provide valuable information to develop integrated project delivery implementation strategies. Additionally, the results of this study can be a proper roadmap to support developing countries to adopt the integrated project delivery approach for project developments.
\end{abstract}

Keywords: Integrated project delivery, Project management, Construction industry, Exploratory factor analysis

\section{INTRODUCTION}

In current times, the construction projects' size and complexity are increasing rapidly. In this sense, projects are considered as temporary social activities done by a group of individuals who interact with each other (Thomsen, 2007). Projects are non-tested final products, whose design may be changed continuously during their implementation (Govender et al., 2018). Generally, increased time and cost and decreased quality of projects are the major causes of conflicts in the construction industry that lead to the reduction of efficiency of this industry (Zaghloul and

\footnotetext{
'Department of Project and Construction Management, MehrAlborz University (MAU), Tehran, IRAN ${ }^{2} \mathrm{School}$ of Construction Economics and Management, University of the Witwatersrand, Johannesburg, SOUTH AFRICA

${ }^{3}$ Department of Corporate Economy, Faculty of Economics and Administration, Masaryk University, Brno, CZECH REPUBLIC

${ }^{4}$ School of Engineering and Technology, Asian Institute of Technology (AIT), Ho Chi Minh, VIETNAM

*Corresponding author: Ehsan.Saghatforoush@wits.ac.za
} 
Hartman, 2003). In traditional contracts, responsibilities are vague and do not specify the consequences of failure and this issue leads to distrust among stakeholders (O' Connor, 2009; Zhang, He and Zhou, 2013).

An essential discussion in the construction industry involves integrated project delivery methods to traditional methods subjects. In this regard, within delivery methods available, integrated project delivery is the most promising method due to the early participation of all stakeholders in the project (Choi et al., 2019). Integrated project delivery applies multilateral agreements and includes a team of architects, engineers and construction experts from several companies. The integrated project delivery is defined as a delivery method that integrates all stakeholders (AIA [American Institute of Architects], 2007; Hall and Scott, 2019). It can be stated that integrated project delivery is a coordinated effort, quality control and cost flexibility contract. Thus stakeholders requirements could be stated as: (1) a joint project team including key project stakeholders who are active in the project's early stages, (2) a synchronous design process that its information is shared, (3) collective risk management, (4) a common goal that leads to the success of the entire project and (5) sharing risks/rewards (Paik et al., 2017; Elghaish, Abrishami and Hosseini, 2020).

In terms of integrated project delivery implementation, the most significant enabler could be considered as raising awareness of the construction industry owners regarding the benefits of such an approach. Then in the next step, it examines the enablers that cover and resolves the weaknesses of contracts with integrated project delivery capabilities. In different countries, according to their laws, there are enablers and disablers for integrated project delivery implementation (Govender et al., 2018). Until now, no study has been conducted to identify and categorise what is needed for proper and complete integrated project delivery implementation.

This study aims to identify and to classify enablers of integrated project delivery implementation. In this study, the literature has been reviewed as well as the integrated project delivery case studies. The principal questions of this study are "What enablers are there for integrated project delivery implementation?" and "In what groups are they classified?". This issue improves the integrity of knowledge (llozor and Kelly, 2012; El Asmar, Hanna and Loh, 2016). As a result, integrated project delivery can be implemented more thoroughly and with fewer defects. Thus, it will result in massive savings in the construction industry and could improve the quality of products produced in the project lifecycle (Molenaar et al., 2009). The next section reviews the research literature.

\section{LITERATURE REVIEW}

Architecture, engineering and construction companies should be prepared to compete in the global market. Global competition leads to the sustainable growth of companies (Yean, Ibbs and Kumaraswamy, 2005). Two critical enablers of staying in the competition could be stated as "having a strong team" and "efficient project delivery methods". Mutual trust, the culture of cooperation and teamwork are essential in the integration of project stakeholders. Open communications and easy access to information are also efficient in improving team integration (Lee et al., 2014; Choi et al., 2019). Project delivery methods can affect team integration (Korkmaz, Swarup and Riley, 2013; Leicht, Townes and Franz, 2017). 
As mentioned, contracts play an essential role and integrated project delivery includes some that have additional items cover (Molenaar et al., 2009; Kahvandi et al., 2016). The definition by the AIA, integrated project delivery integrates individuals, commercial structures, systems and activities related to construction projects in the form of a process. This approach, while attracting partnering and aligning viewpoints of all project stakeholders, reduced wastes, increased value for owners and increased efficiency in all phases of design, pre-construction and construction (AIA, 2007). Table 1 presents a comparison between traditional systems of project delivery and integrated project delivery.

Table 1. Traditional Project Delivery Systems vs Integrated Project Delivery

\begin{tabular}{|c|c|c|}
\hline \multicolumn{2}{|l|}{ Traditional Project Delivery } & \multirow{2}{*}{$\begin{array}{l}\text { Integrated Project Delivery } \\
\text { An integrated team entity } \\
\text { composed key project } \\
\text { stakeholders, assembled early } \\
\text { in the process, open and } \\
\text { collaborative. }\end{array}$} \\
\hline $\begin{array}{l}\text { Assembled on "just-as-needed" } \\
\text { or "minimum-necessary" basis, } \\
\text { strongly hierarchical, controlled. }\end{array}$ & Teams & \\
\hline $\begin{array}{l}\text { Distinct, segregated, knowledge } \\
\text { gathered "just-as-needed", } \\
\text { information hoarded, and silos } \\
\text { of knowledge and expertise. }\end{array}$ & Process & $\begin{array}{l}\text { Multi-level, early contributions } \\
\text { of knowledge and expertise, } \\
\text { information openly shared and } \\
\text { stakeholder trust respect. }\end{array}$ \\
\hline Individually managed. & Risk & $\begin{array}{l}\text { Collectively managed, } \\
\text { appropriately shared. }\end{array}$ \\
\hline $\begin{array}{l}\text { Paper-based, two-dimensional, } \\
\text { and analog. }\end{array}$ & $\begin{array}{l}\text { Communications/ } \\
\text { technology }\end{array}$ & $\begin{array}{l}\text { Digitally based, virtual, and } \\
\text { Building Information Modelling } \\
\text { (three-, four- and five- } \\
\text { dimensional). }\end{array}$ \\
\hline $\begin{array}{l}\text { Individually pursued and } \\
\text { minimum effort for maximum } \\
\text { return. }\end{array}$ & $\begin{array}{l}\text { Compensation/ } \\
\text { reward }\end{array}$ & $\begin{array}{l}\text { Team success tied to project } \\
\text { success and value-based. }\end{array}$ \\
\hline $\begin{array}{l}\text { Encourage unilateral effort, } \\
\text { allocate and transfer risk, and } \\
\text { no sharing. }\end{array}$ & Agreements & $\begin{array}{l}\text { Risk sharing, encourage, foster, } \\
\text { promote and support multilateral } \\
\text { open sharing and collaboration. }\end{array}$ \\
\hline
\end{tabular}

Source: AIA (2007)

The main focus of integrated project delivery is the end goal of the project. Close teamwork allows data to be shared between the construction and design teams simultaneously and improves project efficiency (Rahim, Mohd Nawi and Nifa, 2016). Integrated project delivery seeks to use communication contracts and a single agreement that meets all goals of stakeholders. If necessary, the contracts of material dealers are also added to the contracts. These joint contracts were initially used in countries such as Britain, Australia and New Zealand (Azhar, Kang and Ahmad, 2014). 
In 2012, a case study regarding stakeholders' satisfaction with integrated project delivery projects was published, wherein these projects, planning was implemented realistically (AIA California Council, 2012). Besides, the cost and quality of projects were near to the owners' expectations. In some of these projects, some integrated project delivery principles were implemented and the results were generalisable (Zhang and $\mathrm{Hu}, 2018$ ). Integrated project delivery principles can be applied to other types of contracts, too (Franz and Leicht, 2012; Lee et al., 2014; Kahvandi et al., 2019b). During the conducted studies, a summary of integrated project delivery principles included: (1) respect and trust, (2) innovation, collaboration and decision-making, (3) early participation of project stakeholders, (4) mutual profit and rewards, (5) careful planning of project lifecycle, (6) signing the agreement based on integrated project delivery principles, (7) financial risk and reward based on project results, (8) open communications, (9) a common goal in the project development, (10) risk-sharing and (11) financial transparency among key stakeholders (Kahvandi et al., 2018; Zhang and Hu, 2018). In order to implement integrated project delivery, these principles should be applied in projects (Sive, 2009; Roy, Malsane and Samanta, 2018; Kahvandi et al., 2019a). One of the keys to integrated project delivery success includes "mutual profit and reward" that motivates stakeholders. Many studies have been conducted in the field of fair distribution of profits and integrated project delivery has been more successful in this regard (Teng et al., 2019; Viana et al., 2020). This method has organisational and administrative innovation. Creating this innovation requires some enablers for implementation (Paik et al., 2017).

In terms of enablers, such a subject could be considered as the basis of change. Such change could affect the majority of the stakeholders where the resistance to changes is prevalent; however, in terms of integrated project delivery implementation, such change is necessary (Newton and Chileshe, 2012). Enablers encourage and sustain future activities, and empowerment knowledge is a collection of activities carried out by organisations for a positive and continuous global competition. Generally, enablers include some groups such as the ability of technical knowledge, structural knowledge as well as human knowledge (Yang and Chen, 2007). However, activating enablers requires competent individual and group communications and also coordinating knowledge creation processes with appropriate environments to conduct projects (Von Krogh, Ichijo and Nonaka, 2000). Enablers include two parts which are the ability of individuals, organisations and a facilitating organisational process that includes methods and functions (Maitlis and Lawrence, 2007; Müller, Pemsel and Shao, 2015). Examining and identifying integrated project delivery implementation enablers are significant for the implementation of such a system. So far, no study has been conducted in this regard. The authors have developed a list of integrated project delivery implementation enablers by reviewing various studies conducted in the field of integrated project delivery illustrated in Table 2. 
Table 2. Enablers of Integrated Project Delivery Implementation

\begin{tabular}{cl}
\hline No. & $\begin{array}{l}\text { Items (Enablers of Integrated Project } \\
\text { Delivery Implementation) }\end{array}$ \\
\hline 1 & $\begin{array}{l}\text { Industrial associations and construction } \\
\text { groups' support }\end{array}$ \\
2 & $\begin{array}{l}\text { Government support of integrated } \\
\text { project delivery contracts in the public } \\
\text { sector }\end{array}$ \\
3 & Bankers and financial institutions' support
\end{tabular}

$4 \quad$ Financial ability of companies to accept common risks and profits with customers

5 The technical expertise of companies and using advanced software

6 The ability of companies to manage complex projects

7 The flexibility of rules in accepting changes in industrial and construction contracts

8 A strategic perspective in the organisations towards new implementation systems

9 Strategic plan for the development of the country

10 The possibility of training working groups for cooperation

11 Management support for changing the system

12 The existence of a change management process in contracts

13 The possibility to create open communications and information sharing

14 Proper human resources management

15 Development of a knowledge management system

\section{References}

Kraatz, Sanchez and Hampson (2014) and Mesa, Molenaar and Alarcón (2016).

Azhar, Kang and Ahmad (2014)
and Collins and Parrish (2014).

Derakhshanalavijeh and Teixeira (2017), Pikel, Cheng and Allison (2016) and Yean, lbbs and Kumaraswamy (2005).

Abdirad and Pishdad-Bozorgi (2014) and Sive (2009).

Govender et al. (2018), Kim and Teizer (2014) and Seed (2014).

Ahmad, Azhar and Chowdhury (2019) and Nejati, Javidruzi and Mohebifar (2014).

Bender (2003) and Collins and Parrish (2014).

Klein and Volker (2010) and Lahdenperä (2012).

AIA California Council (2012) and Mesa, Molenaar and Alarcón (2016).

Leicht, Townes and Franz (2017) and Love and Gunasekaran (1997).

Ahmad, Azhar and Chowdhury (2019) and Nejati, Javidruzi and Mohebifar (2014).

Bender (2003) and Lahdenperä (2012).

Abdirad and Pishdad-Bozorgi (2014), Love and Gunasekaran (1997) and Mesa, Molenaar and Alarcón (2016).

Leicht, Townes and Franz (2017) and Zhang, Li and Wu (2013).

Bygballe, Dewulf and Levitt (2015) and Matarneh et al. (2019). 
Table 2. (continued)

\begin{tabular}{|c|c|c|}
\hline No. & $\begin{array}{l}\text { Items (Enablers of Integrated Project } \\
\text { Delivery Implementation) }\end{array}$ & References \\
\hline 16 & $\begin{array}{l}\text { The use of advanced communication } \\
\text { technologies }\end{array}$ & $\begin{array}{l}\text { Becerik-Gerber and Kent (2009) and } \\
\text { Kraatz, Sanchez and Hampson (2014) }\end{array}$ \\
\hline 17 & $\begin{array}{l}\text { The terms of assigning insurance to } \\
\text { project risks }\end{array}$ & $\begin{array}{l}\text { Bygballe, Dewulf and Levitt (2015) } \\
\text { and Ghassemi and Becerik-Gerber } \\
(2011) \text {. }\end{array}$ \\
\hline 18 & $\begin{array}{l}\text { A system for determining the } \\
\text { competence of implementation and } \\
\text { maintenance contractors before } \\
\text { designing }\end{array}$ & $\begin{array}{l}\text { Mollaoglu-Korkmaz, Miller and Sun } \\
\text { (2014) and Popic and Moselhi (2014). }\end{array}$ \\
\hline 19 & $\begin{array}{l}\text { The possibility of cooperation with foreign } \\
\text { partners }\end{array}$ & $\begin{array}{l}\text { Hassan (2013) and Sergi and Berezin } \\
\text { (2018). }\end{array}$ \\
\hline 20 & $\begin{array}{l}\text { Trust and commitment among } \\
\text { stakeholders }\end{array}$ & $\begin{array}{l}\text { Pishdad-Bozorgi and Beliveau (2016) } \\
\text { and Zhang, Huang and Peng (2018). }\end{array}$ \\
\hline 21 & $\begin{array}{l}\text { Availability of resources and the ability } \\
\text { to implement integrated project delivery } \\
\text { system in the country }\end{array}$ & AIA (2007) and Qiang et al. (2015). \\
\hline 22 & $\begin{array}{l}\text { The existence of change factors in } \\
\text { contract systems }\end{array}$ & $\begin{array}{l}\text { Lahdenperä (2012) and Qiang et al. } \\
\text { (2015). }\end{array}$ \\
\hline 24 & $\begin{array}{l}\text { Lack of integrated interoperability } \\
\text { because of lack of necessary technology }\end{array}$ & $\begin{array}{l}\text { Azhar, Kang and Ahmad (2014) and } \\
\text { Collins and Parrish (2014). }\end{array}$ \\
\hline
\end{tabular}

Enablers are the starting point for project implementation to convince and encourage stakeholders' improvement (Govender et al., 2018). As no research has been conducted to examine what is necessary to implement integrated project delivery wholly and correctly, some issues could appear. The next section discusses the research method adopted in this current research.

\section{METHODOLOGY}

The research steps for this study are illustrated in Figure 1 as follows. A 24-item questionnaire has been used as the survey instrument (based on the identified enabler in Table 2), which requested the respondents to rate the importance of each 24 enablers using a nine-point scale with items ranged from 1 (Strongly Low) to 9 (Strongly High). Besides, in the introduction of the questionnaire, we asked the respondents to fill their academic degree, experience in the construction industry and experience in the integrated project delivery area in years. In this research, activists in the construction field in Iran (project managers, employers, consultants and contractors) with a high academic level and more than five years' of integrated project delivery experience participated. 


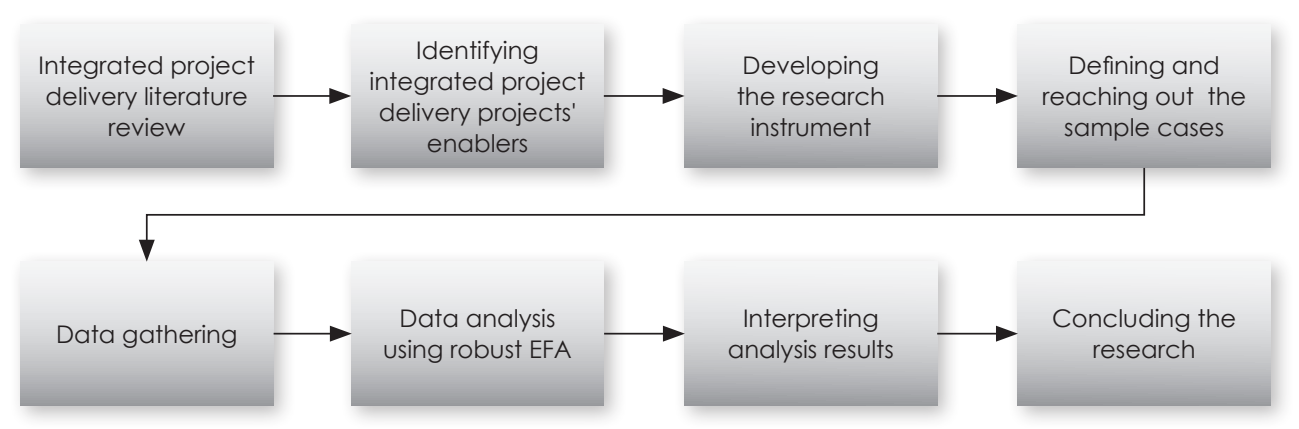

Figure 1. The Research Steps

The collection data process could be identified in three different stages, where: (1) access to the companies and related experts' contact information (emails), (2) fill in the questionnaire and finally (3) collection of filled and replied questionnaires. In order to reach out to the sample, professional networks of the authors plus a local database of Iran Construction Engineering Organization (IRCEO), which lists the title and contact information of construction companies (including their grade), have been used. Through initial contacts with the companies, we identified nearly 400 unique qualified experts (and their email and phone addresses) willing to participate in our research. To ensure that the respondents were qualified to take part in the survey, we highlighted that all respondents should possess more than five years of integrated project delivery experience. Further, all respondents were asked to fill in their academic degree and integrated project delivery experience (in years) within the questionnaire in order to ensure the eligibility of the respondent and validity of the filled questionnaire. In total, 400 questionnaires were sent out to the respondents' emails, where 141 questionnaires were returned (from May to July 2019) and 129 usable questionnaires were used for the data analysis (response rate: 0.32 ). The other 12 questionnaires were removed either due to the significant number of missing data or the lack of required respondents' qualifications. The sample size of 129 was considered adequate to conduct the robust exploratory factor analysis (EFA) (recommended ratio of 5:1) (MacCallum et al., 2001).

\section{RESULTS}

EFA is a statistical method used to uncover the underlying structure of a relatively large set of variables. In this regard, EFA is a technique within factor analysis whose goal is to identify the underlying relationships between measured variables and then to reduce the number of observed variables to fewer enablers to enhance interpretability. Robust EFA (Treiblmaier and Filzmoser, 2010) has been used in this research to perform the analysis. The Kaiser-Meyer-Olkin (KMO) is considered as a measure to verify the data adequacy for FA, aiming to ensure sampling adequacy. The calculated $\mathrm{KMO}$ is 0.73 , which is above the "mediocre" threshold of 0.5 (Kaiser, 1974).

Furthermore, the authors performed a Bartlett sphericity test, which was statistically significant $(p<0.05)$, indicating the eligibility of the data. The authors used a Shapiro-Wilk test to evaluate the normal distribution of data. Based on the 
test results, it was apparent that none of the variables were normally distributed. Thus, the principal component analysis (PCA) was the authors' choice for the factor extraction method as proposed in robust EFA. Oblimin rotation, which is suggested in robust EFA, was used in this research for the rotation method (Treiblmaier and Filzmoser, 2010). Finally, the number of enablers to be extracted from the data were determined based on Eigenvalues greater than one and an absolute factor loading values greater than 0.6 (Chin, Gopal and Salisbury, 1997). As a result, two out of 24 enablers ("The ability of companies to manage complex projects" and "Management support for changing the system") were dropped from the initial pool and the remaining 22 enablers were grouped into four components (columns 1 to 4 in Table 3). The full results can be seen in Table 3.

Table 3. The Results of Robust EFA

\begin{tabular}{|c|c|c|c|c|c|}
\hline No & $\begin{array}{l}\text { Items (Enablers of Integrated Project Delivery } \\
\text { Implementation) }\end{array}$ & 1 & 2 & 3 & 4 \\
\hline 1 & $\begin{array}{l}\text { Financial ability of companies to accept common } \\
\text { risks and profits with customers }\end{array}$ & 0.68 & & & \\
\hline 2 & $\begin{array}{l}\text { The ability of companies to manage complex } \\
\text { projects }\end{array}$ & 0.81 & & & \\
\hline 3 & Management support for changing the system & 0.77 & & & \\
\hline 4 & Proper human resources management & 0.68 & & & \\
\hline 5 & $\begin{array}{l}\text { A system for determining the competence of } \\
\text { implementation and maintenance contractors } \\
\text { before designing }\end{array}$ & 0.81 & & & \\
\hline 6 & $\begin{array}{l}\text { A strategic perspective in the organisations } \\
\text { towards new implementation systems }\end{array}$ & 0.68 & & & \\
\hline 7 & $\begin{array}{l}\text { The possibility of training working groups for } \\
\text { cooperation }\end{array}$ & 0.71 & & & \\
\hline 8 & $\begin{array}{l}\text { Development of a knowledge management } \\
\text { system }\end{array}$ & 0.73 & & & \\
\hline 9 & Trust and commitment among stakeholders & 0.60 & & & \\
\hline 10 & $\begin{array}{l}\text { Industrial associations and construction groups' } \\
\text { support }\end{array}$ & & 0.81 & & \\
\hline 11 & Bankers and financial institutions' support & & 0.65 & & \\
\hline 12 & Strategic plan for the development of the country & & 0.86 & & \\
\hline 13 & $\begin{array}{l}\text { Availability of resources and the ability to } \\
\text { implement integrated project delivery system in } \\
\text { the country }\end{array}$ & & 0.69 & & \\
\hline 14 & $\begin{array}{l}\text { Government support of integrated project delivery } \\
\text { contracts in the public sector }\end{array}$ & & & 0.71 & \\
\hline 15 & The existence of change factors in contract systems & & & 0.68 & \\
\hline 16 & $\begin{array}{l}\text { The existence of a change management process } \\
\text { in contracts }\end{array}$ & & & 0.86 & \\
\hline
\end{tabular}


Table 3. (continued)

\begin{tabular}{|c|c|c|c|c|c|}
\hline No & $\begin{array}{l}\text { Items (Enablers of Integrated Project Delivery } \\
\text { Implementation) }\end{array}$ & 1 & 2 & 3 & 4 \\
\hline 17 & The terms of assigning insurance to project risks & & & 0.71 & \\
\hline 18 & The possibility of cooperation with foreign partners & & & 0.78 & \\
\hline 19 & $\begin{array}{l}\text { The flexibility of rules in accepting changes in } \\
\text { industrial and construction contracts }\end{array}$ & & & 0.66 & \\
\hline 20 & $\begin{array}{l}\text { The technical expertise of companies and using } \\
\text { advanced software }\end{array}$ & & & & 0.81 \\
\hline 21 & $\begin{array}{l}\text { The possibility to create open communications and } \\
\text { information sharing }\end{array}$ & & & & 0.67 \\
\hline \multirow[t]{3}{*}{22} & The use of advanced communication technologies & & & & 0.76 \\
\hline & $\%$ of variance & 21.12 & 20.04 & 16.05 & 13.24 \\
\hline & Cumulative \% & & 41.16 & 57.21 & 70.45 \\
\hline
\end{tabular}

Note: The extraction method used is the PCA and the rotation method used is Oblimin.

The next step would be indicating the meaning of the components. In order to perform, the authors used the experts' opinions. Following, three integrated project delivery project managers were selected, where all had a high academic degree and the integrated project delivery experience of over seven years. Here, three integrated project delivery project managers were invited and based on the discussions on the enablers' meanings in each component; four "organisational", "environmental", "contractual" and finally "technical" labels were assigned to the extracted components. The final results are shown in Table 4.

Table 4. Extracted Components and Their Related Enablers

\begin{tabular}{|c|c|}
\hline Component Name & Enablers \\
\hline \multirow[t]{9}{*}{ Organisational } & The ability of companies to manage complex projects \\
\hline & $\begin{array}{l}\text { A system for determining the competence of implementation } \\
\text { and maintenance contractors before designing }\end{array}$ \\
\hline & Management support for changing the system \\
\hline & Development of a knowledge management system \\
\hline & The possibility of training working groups for cooperation \\
\hline & $\begin{array}{l}\text { Financial ability of companies to accept common risks and } \\
\text { profits with customers }\end{array}$ \\
\hline & Proper human resources management \\
\hline & $\begin{array}{l}\text { A strategic perspective in the organisations towards new } \\
\text { implementation systems }\end{array}$ \\
\hline & Trust and commitment among stakeholders \\
\hline
\end{tabular}


Table 4. (continued)

\begin{tabular}{|c|c|}
\hline Component Name & Enablers \\
\hline \multirow[t]{4}{*}{ Environmental } & Strategic plan for the development of the country \\
\hline & Industrial associations and construction groups' support \\
\hline & $\begin{array}{l}\text { Availability of resources and the ability to implement } \\
\text { integrated project delivery system in the country }\end{array}$ \\
\hline & Bankers and financial institutions' support \\
\hline \multirow[t]{6}{*}{ Contractual } & The existence of a change management process in contracts \\
\hline & The possibility of cooperation with foreign partners \\
\hline & The terms of assigning insurance to project risks \\
\hline & $\begin{array}{l}\text { Government support of integrated project delivery contracts } \\
\text { in the public sector }\end{array}$ \\
\hline & The existence of change factors in contract systems \\
\hline & $\begin{array}{l}\text { The flexibility of rules in accepting changes in industrial and } \\
\text { construction contracts }\end{array}$ \\
\hline \multirow[t]{3}{*}{ Technical } & $\begin{array}{l}\text { The technical expertise of companies and using advanced } \\
\text { software }\end{array}$ \\
\hline & The use of advanced communication technologies \\
\hline & $\begin{array}{l}\text { The possibility to create open communications and } \\
\text { information sharing }\end{array}$ \\
\hline
\end{tabular}

Tables 3 and 4 illustrate that organisational enablers have the highest priority. This category is considered as the most crucial enablers of companies' abilities to manage complex projects. The environmental enablers are considered as the second one and the most important of them is the support of industry associations and construction groups. The next one is the contractual category and its most important enabler is the existence of a change management process in contracts. The last one is the technical enablers.

\section{DISCUSSION}

The findings of this current research show that organisational enablers are considered essential than other enablers. Then, environmental enablers are of interest to the stakeholders and the following ones are contractual and technical enablers. Planning for resources of organisations is vital due to the stakeholders' alignment with the project goals. The ability of companies to manage complex projects was considered as one of the enablers that have the most impact on projects. Integrated project delivery has a high ability to resolve problems of complex projects, including therapeutic projects (AIA California Council, 2012). The existence of a system that determines maintenance contractors before designing is crucial to boost trust among stakeholders (Pishdad-Bozorgi and Beliveau, 2016). Changing the implementation system from traditional systems into integrated project delivery requires the support and desire of the organisations' management 
department. Therefore, management support for changing a system is considered as a critical enabler.

Moreover, after that, the organisation's management acceptance to change the system, the training of working groups for cooperation is an essential component of integrated project delivery implementation (Zhang, Li and WU, 2013). In today's advanced world, knowledge is rapidly turning into a leading competitive advantage of organisations. Recognising knowledge, as an organisational source, supports creating a new field of knowledge management in information systems. These advances show that knowledge is in various forms of assets and human capital (Anumba et al., 2008). Thus, developing a knowledge management system is a critical enabler. Human resources are one of the most crucial resources of each organisation. Organisations need to take adequate measures in the area of human resources management to achieve their goals and implement their strategies (Al Ahbabi, 2014). Proper human resources management in organisations also contributes to the trust and commitment of stakeholders. Efficient teamwork is an essential principle in integrated project delivery (Manata et al., 2018). Another integrated project delivery principle is mutual risk and profit among stakeholders. The financial capability of companies to accept common risks and profits with the customer enables them to accept integrated project delivery (AIA, 2007).

In terms of environmental enablers, the inclusion of those that are not influenced by the organisation or are considered negligible can play a critical role in the organisation's future. An organisation's strategy is successfully implemented when environmental enablers are considered. One of the essential environmental enablers in integrated project delivery implementation is the strategic plan for the development of a country, which should be considered in the country's macro planning. On the other hand, it leads to the availability of resources and integrated project delivery implement ability in the country (Jalaei and Jrade, 2015). If large industrial groups support integrated project delivery implementation, it will help companies significantly. Besides, the support of bankers and financial institutions of the country is considered an important environmental enabler, since the rules of compensation in projects is fundamental (Cohen, 2010).

Contractual enablers are significant in the project implementation systems, where each contract has a particular cycle and an appropriate strategy to manage the cycle. Commonly, writing and signing a contract is complicated and time-consuming. The complexity could be address as the proper company development, where the deficiency could generate losses and several negative consequences. Disputes in contracting contracts may be due to several reasons and the existence of changes in the implementation cycle is considered significant. The existence of the change management process in the contracts of organisations, the existence of change issues in contract systems and the flexibility of rules in accepting changes of contracts could lead to resolving disputes (Lee et al., 2014). The public sector has not had supported integrated project delivery, while many sensitive projects are being implemented in this sector (Collins and Parrish, 2014). Integrated project delivery contracts require specific conditions that should be provided by the insurer, and as a result, the conditions for assigning insurance to project risks should be developed. In recent years, integrated project delivery users have made some changes in the traditional insurance contracts to benefit from insurance conditions. On the other hand, the conditions for assigning insurance to project risks also provide cooperation with foreign partners (Ghassemi and Becerik-Gerber, 2011 ). 
The technology could be considered as one of the organisation drivers of growth and development. Therefore, the technical expertise of companies and the use of advanced software could be an essential step in the integrated project delivery implementation. One of the integrated project delivery essential principles is the ability to provide open communications and sharing information. On the other hand, if countries have advanced communication technologies, it will be a promising process of integrated project delivery implementation (Hess, 2009; Kent and Becerik-Gerber, 2010).

The classification obtained in this research is mostly in line with several owners' concerns within the construction industry. The classification of enablers has been based on the experience of several engineers, consultants and contractors that consider the existence of a comprehensive and coordinated system necessary in the construction industry in order to resolve several issues. On the other hand, it can be stated that in this research, important enablers have been specified, so that is possible to remove disablers through creating and reinforcing them. All the enablers identified will be vital and useful because the suitable ways to execute projects can save substantial financial and time capital.

\section{CONCLUSIONS}

In this study, a list of integrated project delivery implementation enablers was prepared using a literature review. From the list, 22 items were examined and categorised into four groups of organisational, environmental, contractual and technological enablers. The results of this study show that organisational enablers are essential in integrated project delivery implementation. What is central is that integrated project delivery implementation requires various and critical enablers that help many organisations. However, the experience of applying integrated project delivery in other countries indicates that its success in saving time and cost is crucial in the project lifecycle. This study is based on a limited number of linked cases in Iran as a fast developing country. The information that was used is limited to available data, mainly from databases. In the future, an interview should be conducted with the stakeholders involved in the projects.

Future studies in this field should focus on integrated project delivery case studies, paying more attention to enablers and consider key enablers by using other methods. On the other hand, the impact of these enablers on project outcomes such as time, cost and quality should also be explored.

\section{REFERENCES}

Abdirad, H. and Pishdad-Bozorgi, P. (2014). Trends of assessing BIM implementation in construction research. In Computing in Civil and Building Engineering. Orlando, FL: American Society of Civil Engineers. https://doi.org/10.1061/9780784413616.062.

Ahmad, I., Azhar, N. and Chowdhury, A. (2019). Enhancement of IPD characteristics as impelled by information and communication technology. Journal of Management in Engineering, 35(1): 04018055. https://doi.org/10.1061/ (ASCE)ME.1943-5479.0000670. 
AIA (American Institute of Architects) (2007). Integrated Project Delivery: A Guide. Washington DC: AIA.

AIA California Council (2012). IPD Case Studies. Minnesota: AIA, AIA Minnesota, School of Architecture University of Minnesota. Available at: https://rp.design.umn.edu/resources/documents/IPD-Case-Study-Matrix -2012_corrected02.pdf.

Al Ahbabi, M.S. (2014). Process protocol for the implementation of integrated project delivery in the UAE: A client perspective. PhD diss. University of Salford.

Anumba, C.J., Issa, R.R.A., Pan, J. and Mutis, I. (2008). Ontology-based information and knowledge management in construction. Construction Innovation, 8(3): 218-239. https://doi.org/10.1108/14714170810888976.

Azhar, N., Kang, Y. and Ahmad, I.U. (2014). Factors influencing integrated project delivery in publicly owned construction projects: An information modelling perspective. Procedia Engineering, 77: 213-221. https://doi.org/10.1016/ j.proeng.2014.07.019.

Becerik-Gerber, B. and Kent, D.C. (2010). Implementation of integrated project delivery and Building Information Modeling on a small commercial project. International Journal of Project Management, 1-6.

. (2009). Integrated project delivery and Building Information Modeling on a small commercial project. Paper presented at the Associated Schools of Construction 45th Annual International Conference. University of Florida, United States, 1-4 April.

Bender, W.J. (2003). Case study of construction project delivery types. In K.R. Molenaar and P.S. Chinowsky (eds.), Construction Research Congress 2003. Reston, VA: American Society of Civil Engineers. https://doi.org/10.1061/40671 (2003)84.

Bygballe, L.E., Dewulf, G. and Levitt, R.E. (2015). The interplay between formal and informal contracting in integrated project delivery. Engineering Project Organization Journal, 5(1): 22-35. https://doi.org/10.1080/21573727.2014 .992014.

Chin, W., Gopal, A. and Salisbury, W. (1997). Advancing the theory of adaptive structuration: The development of a scale to measure faithfulness of appropriation. Information Systems Research, 8(4): 342-367. https://doi.org/ 10.1287/isre.8.4.342.

Choi, J., Yun, S., Leite, F. and Mulva, S.P. (2019). Team integration and owner satisfaction: Comparing integrated project delivery with construction management at risk in health care projects. Journal of Management in Engineering, 35(1): 1-11. https://doi.org/10.1061/(ASCE)ME.1943-5479 .0000654 .

Cohen, J. (2010). Integrated project delivery: Case studies. Journal of Legal Affairs and Dispute Resolution in Engineering and Construction, 2(November): 248254.

Collins, W. and Parrish, K. (2014). The need for integrated project delivery in the public sector. In D. Castro-Lacouture, J. Irizarry and B. Ashuri (eds.), Construction Research Congress 2014. Reston, VA: American Society of Civil Engineers, 719-728. https://doi.org/10.1061/9780784413517.074.

Derakhshanalavijeh, R. and Teixeira, J.M.C. (2017). Cost overrun in construction projects in developing countries: Gas-oil industry of Iran as a case study. Journal of Civil Engineering and Management, 23(1): 125-136. https://doi.org/10.3846/13923730.2014.992467. 
El Asmar, M., Hanna, A.S. and Loh, W.Y. (2016). Evaluating integrated project delivery using the project quarterback rating. Journal of Construction and Engineering Management, 142(1): 1-13. https://doi.org/10.1061/(ASCE)CO .1943-7862.0001015.

Elghaish, F., Abrishami, S. and Hosseini, M.R. (2020). Integrated project delivery with blockchain: An automated financial system. Automation in Construction, 114: 103182. https://doi.org/10.1016/j.autcon.2020.103182.

Franz, B. and Leicht, R. (2012). Initiating IPD concepts on campus facilities with a "Collaboration Addendum". In H. Cai, A. Kandil, M. Hastak and P.S. Dunston (eds.), Construction Research Congress 2012. Reston, VA: American Society of Civil Engineers, 61-70. https://doi.org/10.1061/9780784412329.007.

Ghassemi, R. and Becerik-Gerber, B. (2011). Transitioning to integrated Integrated Project Delivery: Potential barriers and lessons learned. Lean Construction Journal, 2011:32-52.

Govender, K., Nyagwachi, J., Smallwood, J.J. and Allen, C.J. (2018). The awareness of integrated project delivery and building information modelling: Facilitating construction projects. International Journal of Sustainable Development and Planning, 13(1): 121-129. https://doi.org/10.2495/SDP-V13-N1-121-129.

Hall, D.M. and Scott, W.R. (2019). Early stages in the institutionalization of integrated project delivery. Project Management Journal, 50(2): 1-16. https://doi.org/ $10.1177 / 8756972818819915$.

Hassan, M.E. (2013). Assessing the impact of lean/integrated project delivery system on final project success. PhD diss. George Mason University.

Hess, R. (2009). B.I.M. solving the problems in design-to-construction implementation that we have created? In Annual Convention of the Structural Engineers Association of California 2009 (SEAOC 2009). California: Structural Engineers Association of California, 475-486.

llozor, B.D. and Kelly, D.J. (2012). Building information modeling and integrated project delivery in the commercial construction industry: A conceptual study. Journal of Engineering, Project and Production Management, 2(1): 23-36. https://doi.org/10.32738/JEPPM.201201.0004.

Jalaei, F. and Jrade, A. (2015). Integrating building information modeling (BIM) and LEED system at the conceptual design stage of sustainable buildings. Sustainable Cities and Society, 18: 95-107. https://doi.org/10.1016/j.scs .2015.06.007.

Kahvandi, Z., Saghatforoush, E., Alinezhad, M. and Preece, C. (2016). Analysis of research trends on benefits of implementing integrated project delivery (IPD). Paper presented at the International Conference on Civil, Mechanical Engineering and Construction Management (CMC 2016). Kuala Lumpur, Malaysia, 8 December.

Kahvandi, Z., Saghatforoush, E., Mahoud, M. and Preece, C. (2019a). Analysis of the barriers to the implementation of integrated project delivery (IPD): A meta-synthesis approach. Journal of Engineering, Project, and Production Management, 9(1): 2-11. https://doi.org/10.2478/jeppm-2019-0002.

Kahvandi, Z., Saghatforoush, E., ZareRavasan, A. and Mansouri, T. (2018). An FCMbased dynamic modelling of integrated project delivery implementation challenges in construction projects. Lean Construction Journal, 87: 63-87. 
Kahvandi, Z., Saghatforoush, E., ZareRavasan, A. and Preece, C. (2019b). Integrated project delivery implementation challenges in the construction industry. Civil Engineering Journal, 5(8): 1672-1683. https://doi.org/10.28991/cej $-2019-03091362$.

Kaiser, H. (1974). An index of factorial simplicity. Psychometrika, 39: 31-36. https://doi.org/10.1007/BF02291575.

Kent, D.C. and Becerik-Gerber, B. (2010). Understanding construction industry experience and attitudes toward integrated project delivery. Journal of Construction Engineering and Management, 136(8): 815-825. https://doi.org/10.1061/(ASCE)CO.1943-7862.0000188.

Kim, K. and Teizer, J. (2014). Automatic design and planning of scaffolding systems using building information modelling. Advanced Engineering Informatics, 28: 66-80.

Klein, R. and Volker, L. (2010). Participating in integrated project delivery: The future mainspring of architectural design firms? Gestao \& Tecnologia de Projectos, 5(3): 37-49. https://doi.org/10.4237/gtp.v5i3.181.

Korkmaz, S., Swarup, L. and Riley, D. (2013). Delivering sustainable, high performance buildings: Influence of project delivery methods on integration and project outcomes. Journal of Management in Engineering, 29(1): 71-78. https://doi.org/10.1061/(ASCE)ME.1943-5479.0000114.

Kraatz, J.A., Sanchez, A.X. and Hampson, K.D. (2014). Digital modeling, integrated project delivery and industry transformation: An Australian case study. Buildings, 4(3): 453-466. https://doi.org/10.3390/buildings4030453.

Lahdenperä, P. (2012). Making sense of the multi-party contractual arrangements of project partnering, project alliancing and integrated project delivery. Construction Management and Economics, 30(1): 57-79. https://doi.org/ 10.1080/01446193.2011.648947.

Lee, H.W., Anderson, S.M., Kim, Y.W. and Ballard, G. (2014). Advancing impact of education, training and professional experience on integrated project delivery. Practice Peridocal on Structural Design and Construction, 19(1): 8-14. https://doi.org/10.1061/(ASCE)SC.1943-5576.0000190.

Leicht, R., Townes, A. and Franz, B. (2017). Collaborative team procurement for integrated project delivery: A case study. Lean Construction Journal, 64: 4964.

Love, P.E.D. and Gunasekaran, A. (1997). Concurrent engineering in the construction industry. Concurrent Engineering, 5(2): 155-162. https://doi.org/10.1177/10632 93X9700500207.

MacCallum, R.C., Widaman, K.F., Preacher, K.J. and Hong, S. (2001). Sample size in factor analysis: The role of model error. Multivariate Behavioral Research, 36(4): 61 1-637. https://doi.org/10.1207/S15327906MBR3604_06.

Maitlis, S. and Lawrence, T.B. (2007). Triggers and enablers of sensegiving in organizations. Academy of Management Journal, 50(1): 57-84. https://doi .org/10.5465/amj.2007.24160971.

Manata, B., Miller, V., Mollaoglu, S. and Garcia, A.J. (2018). Measuring key communication behaviors in integrated project delivery teams. Journal of Management in Engineering, 34(4): 1-7. https://doi.org/10.1061/(ASCE) ME.1943-5479.0000622. 
Matarneh, S.T., Danso-Amoako, M., Al-Bizri, S., Gaterell, M. and Matarneh, R. (2019). Building information modeling for facilities management: A literature review and future research directions. Journal of Building Engineering, 24: 100755. https://doi.org/10.1016/j.jobe.2019.100755.

Mesa, H.A., Molenaar, K.R. and Alarcón, L.F. (2016). Exploring performance of the integrated project delivery process on complex building projects. International Journal of Project Management, 34(7): 1089-1101. https://doi.org/10.1016/ j.ijproman.2016.05.007.

Molenaar, K., Sobin, N., Gransberg, D., McCuen, T., Korkmaz, S. and Horman, M. (2009). Sustainable, High Performance Projects and Project Delivery Methods: A State-of-Practice Report. California: Charles Pankow Foundation and the Design-Build Institute of America (DBIA).

Mollaoglu-Korkmaz, S., Miller, V.D. and Sun, W. (2014). Assessingkey dimensions to effective innovation implementation in interorganizational project teams: An integrated project delivery case. The Engineering Project Organization Journal, 4(1): 17-30. http://doi.org/10.1080/21573727.2013.855895.

Müller, R., Pemsel, S. and Shao, J. (2015). Organizational enablers for project governance and governmentality in project-based organizations. International Journal of Project Management, 33(4): 839-851. https://doi .org/10.1016/j.ijproman.2014.07.008.

Nejati, I., Javidruzi, M. and Mohebifar, A.H. (2014). Feasibility of using an integrated project delivery (IPD) in mass housing collaborative projects. Advances in Environmental Biology, 8(25): 211-218.

Newton, K.L. and Chileshe, N. (2012). Enablers and barriers of Building Information Modelling (BIM) within South Australian construction organisations. Proceedings of the 37th Annual Conference of Australian University Building Educators Association (AUBEA). Sydney: The University of New South Wales. https://doi.org/10.13140/2.1.4964.1607.

O' Connor, J.P.J. (2009). Integrated Project Delivery: Collaboration through New Contract Forms. Minneapolis: Faegre \& Benson LLP.

Paik, J.E., Miller, V., Mollaoglu, S. and Sun, W.A. (2017). Interorganizational projects: Reexamining innovation implementation via IPD cases. Journal of Management in Engineering, 33(5): 1-15. https://doi.org/10.1061/(ASCE)ME .1943-5479.0000524.

Pikel, C., Cheng, R. and Allison, M. (2016). Motivation and Means: How and Why IPD and Lean Lead to Success. Arlington, VA: Lean Construction Institute and Integrated Project Delivery Alliance.

Pishdad-Bozorgi, P. and Beliveau, Y.J. (2016). A schema of trust building attributes and their corresponding integrated project delivery traits. International Journal of Construction Education and Research, 12(2): 142-160. https://doi.org/10.1080/15578771.2015.1118171.

Popic, Z. and Moselhi, O. (2014). Project delivery systems selection for capital projects using the analytical hierarchy process and the analytical network process. In D. Castro-Lacouture, J. Irizarry and B. Ashuri (eds.), Construction Research Congress 2014. Reston, VA: American Society of Civil Engineers, 1339-1348. https://doi.org/10.1061/9780784413517.137.

Qiang, M., Wen, Q., Jiang, H. and Yuan, S. (2015). Factors governing construction project delivery selection: A content analysis. International Journal of Project Management, 33(8): 1780-1794. https://doi.org/10.1016/j.ijproman .2015.07.001. 
Rahim, S.A., Mohd Nawi, M.N. and Nifa, F.A.A. (2016). Integrated project delivery (IPD): A collaborative approach to improve the construction industry. Advanced Science Letters, 22(5-6): 1331-1335. https://doi.org/10.1166/asl .2016 .6764 .

Roy, D., Malsane, S. and Samanta, P.K. (2018). Identification of critical challenges for adoption of integrated project delivery. Lean Construction Journal, 15: 1-15.

Seed, W.R. (2014). Integrated project delivery requires a new project manager. Proceedings IGLC-22. Oslo, Norway: The International Group for Lean Construction, 1447-1459.

Sergi, B.S. and Berezin, A. (2018). Oil and gas industry's technological and sustainable development: Where does Russia stand? In B.S. Sergi (ed.), Exploring the Future of Russia's Economy and Markets. Bingley, UK: 161-182. https://doi.org/10.1108/978-1-78769-397-520181009.

Sive, T. (2009). Integrated project delivery: Reality and promise; A strategist's guide to understanding and marketing IPD. Society for Marketing Professional Services Foundation White Paper on IPD, SMPS Publication. Alexandria, VA: Society for Marketing Professional Services.

Teng, Y., Li, X., Wu, P. and Wang, X. (2019). Using cooperative game theory to determine profit distribution in IPD projects. International Journal of Construction Management, 19(1): 32-45. https://doi.org/10.1080/15623599.2 017.1358075 .

Thomsen, C. (2007). Managing integrated project delivery: Concepts and contract strategies. CMAA, 35: 1-52.

Treiblmaier, H. and Filzmoser, P. (2010). Exploratory factor analysis revisited: How robust methods support the detection of hidden multivariate data structures in IS research. Information and Management, 47(4): 197-207. https://doi.org/10.1016/j.im.2010.02.002.

Viana, M.L., Hadikusumo, B.H.W., Mohammad, M.Z. and Kahvandi, Z. (2020). Integrated project delivery (IPD): An updated review and analysis case study. Journal of Engineering, Project and Production Management, 10(2): 147-161. https://doi.org/10.2478/jeppm-2020-0017.

Von Krogh, G., Ichijo, K. and Nonaka, I. (2000). Enabling Knowledge Creation: How to Unlock the Mystery of Tacit Knowledge and Release the Power of Innovation. Oxford: Oxford University Press.

Yang, C. and Chen, L. (2007). Can organizational knowledge capabilities affect knowledge sharing behavior? Journal of Information Science, 33(1): 95-109. https://doi.org/10.1177/0165551506068135.

Yean, F.Y.L., Ibbs, C.W. and Kumaraswamy, M.M. (2005). Enablers that help foreign architectural, engineering and construction firms win construction contracts in China. Journal of Management in Engineering, 21 (2): 63-69. https://doi. org/10.1061/(ASCE)0742-597X(2005)21:2(63).

Zaghloul, R. and Hartman, F. (2003). Construction contracts: The cost of mistrust. International Journal of Project Management, 21(6): 419-424. https://doi.org/10.1016/S0263-7863(02)00082-0.

Zhang, L., He, J. and Zhou, S. (2013). Sharing tacit knowledge for integrated project team flexibility: Case study of integrated project delivery. Journal of Construction Engineering and Management, 139(7): 795-805. https://doi.org/10.1061/(ASCE)CO.1943-7862.0000645. 
Zhang, L., Huang, S. and Peng, Y. (2018). Collaboration in integrated project delivery: The effects of trust and formal contracts. Engineering Management Journal, 30(4): 262-273. https://doi.org/10.1080/10429247.2018.1498259.

Zhang, L., Li, Y. and WU, Q. (2013). Evaluation on collaborative satisfaction for project management team in integrated project delivery mode. Journal of The Institution of Engineers (India): Series A, 94(2): 109-115. https://doi.org/10.1007/s40030-013-0041-z.

Zhang, Y. and Hu, H. (2018). Utilization of a cognitive task analysis for integrated project delivery application: Case study of constructing a campus underground parking facility. Cognitive Systems Research, 52: 579-590. https://doi.org/10.1016/j.cogsys.2018.08.003. 